\title{
ANALISIS KEBUTUHAN DAN KETERSEDIAAN AIR KABUPATEN MANOKWARI DENGAN MODEL MOCK
}

\author{
(Analysis of water demand and supply in Kabupaten Manokwari with Mock Model) \\ Prima Jiwa Osly ${ }^{1}$, Irfan Ihsani ${ }^{1}$, Rhonny Einsten Ririhena ${ }^{2}$, Fulki Dwiyandi Araswati ${ }^{3}$ \\ ${ }^{1}$ Universitas Pancasila \\ ${ }^{2}$ Universitas Pattimura \\ ${ }^{3}$ Institut Pertanian Bogor \\ E-mail : primaiiwa.osly@univpancasila.ac.id
}

\begin{abstract}
ABSTRAK
Air merupakan salah satu sumber kehidupan, karena air adalah zat atau unsur esensial bagi kehidupan manusia dan mahluk hidup lainnya. Dapat dikatakan tidak ada kehidupan di muka bumi ini yang dapat berlangsung tanpa air. Tanpa ketersediaan air yang mencukupi kebutuhan manusia dan makhluk hidup lainnya dapat mengakibatkan terjadinya konflik. Maka dalam penelitian ini bertujuan untuk menganalisis seberapa besar potensi ketersediaan air berdasarkan debit andalan dan seberapa besar kebutuhan air di Kabupaten Manokwari. Ketersediaan air di Kabupaten Manokwari ini di harapkan dapat memenuhi kebutuhan wilayah tersebut secara kuantitatif. Analisis yang digunakan dalam penelitian ini menggunakan metode FJ. Mock. Metode ini dilakukan dengan mengaplikasikan pendekatan model hujan aliran (rainfall-run off model) dengan menggunakan data curah hujan, evapotranspirasi potensial, dan karakteristik hidrologi untuk memprediksi besar debit sungai dengan interval waktu bulanan. Hasil penelitian ini menunjukan debit andalan tahunan yang diperoleh dengan kemungkinan terpenuhi $50 \%$ adalah sebesar $\mathrm{Q}=178.352\left(\mathrm{~m}^{3} / \mathrm{det}\right)$ dan debit andalan $80 \%$ sebesar $\mathrm{Q}=152.405\left(\mathrm{~m}^{3} / \mathrm{det}\right)$. Potensi ketersediaan air pada kabupaten Manokwari pada tahun 2018 adalah sebesar $398.570 .549 \mathrm{~m}^{3}$ dan total kebutuhan air untuk penggunaan sebanyak $66.629 .639 \mathrm{~m}^{3}$, sehingga kabupaten Manokwari memiliki surplus air baku yang dapat lebih dimanfaatkan.
\end{abstract}

Kata Kunci : Ketersediaan air, kebutuhan air, debit andalan, fj mock

\begin{abstract}
Water is one of living resource, because the water is an essential substance or constituent for human's and other living life. There is no life on earth that may last without water. If the water supply is not enough for the needs of humans and other living beings, there will be conflicts between or among them. Due to the consideration, this research is aimed to analyze how much is the of water supply pottential based on dependable flow and how much is the demand of water in Kabupaten Manokwari. The water supply in Kabupaten Manokwari is meant to fulfill the water demand in this region quantitatively. This research is using analysis by the FJ. Mock methods. FJ. Mock mmethod uses rainfall-run off model by using rainfall data, potential evapotranspiration, and characteristics hydrology for predicting the number of river discharge by the monthly period. The result of this research is shows that annual dependable flow to the possibility of fulfilled $50 \%$ is equal to $Q=178.352(\mathrm{~m} 3 / \mathrm{det})$ and discharge andalan $80 \%$ is $\mathrm{Q}=$ 152.405 ( $\left.\mathrm{m}^{3} / \mathrm{det}\right)$. The potential for water supply in Kabupaten Manokwari in 2018 is $398570549 \mathrm{~m}^{3}$ and the total water demand for use as many as $66.629 .639 \mathrm{~m}^{3}$, kabupaten Manokwari having a surplus of raw water that could be used more.
\end{abstract}

Keywords: Water supply, water demand, dependable flow, FJ Mock 


\section{PENDAHULUAN}

Perkembangan suatu kota tidak akan terlepas dari faktor penduduk dan aktivitas kehidupannya yang selalu meningkat, terjadinya pertambahan jumlah penduduk berpengaruh terhadap proses pembangunan pada suatu wilayah dan meningkatnya kebutuhan akan ruang perkotaan. Seiring dengan pertumbuhan pendudukyang semakin pesat berbanding lurus dengan bertambahnya pemenuhan kebutuhan, salah satunya adalah sumber daya air. Sumber daya air sungai merupakan usaha untuk menyediakan dan memanfaatkan air untuk menunjang kehidupan manusia.

Air yang terkandung dalam suatu wilayah merupakan sumber alam terpenting bagi kehidupan mahkluk hidup, tetapi ketersediaannya tidak selalu sejalan dengan kebutuhannya. Seiring dengan jumlah penduduk yang makin bertambah setiap tahunnya. Dampak ini akan berpengaruh pada aktifitas masyarakat untuk memenuhi kebutuhan air berdasarkan jejak air, sehingga kondisi wilayah tersebut dapat diketahui supplay-demand. Jejak air dapat menjelaskan jumlah total volume air untuk menghasilkan barang atau jasa guna memenuhi konsumsi seseorang atau kelompok orang (Satrio, 2018).

Kabupaten Manokwari merupakan ibu kota Provinsi Papua Barat merupakan salah satu kabupaten yang sedang berkembang. Perkembagan kabupaten Manokwari dapat dilihat dari meningkatnya jumlah penduduk maupun perekonomiannya. Dengan perkembangan ini makan perlu diperhatikan adalah penyediaan air minum dan sumber daya air permukaan lainnya yang meliputi saluran irigasi, sungai dan situ merupakan bagian dari aspek sumberdaya air (SDA) guna menunjang kebutuhan. Berdasarkan latar belakang tersebut tujuan studi ini adalah untuk mengetahui potensi ketersediaan atau debit andalan sumber air di Kabupaten Manokwari. Selain itu tujuan dari penelitian ini adalah mengetahui sebebrapa besar potensi ketersediaan air berdasarkan data debit andalan dan seberapa besar kebutuhan air di Kabupaten Manokwari secara menyeluruh.

\section{METODE PENELITIAN}

Studi kasus penelitian ini berada di Provinsi Papua Barat lebih tepatnya di Kabupaten Manokwari, yang merupakan ibu kota dari Provinsi Papua Barat. Penelitian ini dimaksud untuk mengetahui ketersediaan air di Kabupaten Manokwari dengan cara menganalisis potensi atau ketersediaan debit sungai dengan menggunakan Metode FJ. MOCK.

\section{Analisis Ketersediaan Air}

Model yang digunakan untuk menghitung ketersediaan air di Kabupaten Manokwari dilakukan dengan mengaplikasikan pendekatan model hujan aliran (rainfall-run off model) dengan menggunakan data curah hujan, evapotranspirasi potensial, dan karakteristik hidrologi untuk memprediksi besar debit sungai dengan interval waktu bulanan (Gustiana, 2014). Model ini dikenal dengan nama model Dr. F.J. Mock. Dimana dalam Model Mock adalah salah satu model hidrologi yang sering digunakan di Indonesia untuk menghitung ketersediaan air suatu sungai berdasarkan data hujan sebagai masukan model, disamping beberapa metode yang lain seperti metode tangki Sugawara dan metode SMEC. Sistem kerja model ini mengikuti prinsip water balance untuk memperkirakan ketersediaan air (debit) suatu sungai. Secara kusus, Model Mock dapat diterapkan apabila data debit sungai tidak tersedia (walaupun ada, akan tetapi rentang data tidak memadai untuk perhitungan). Informasi data debit didasarkan pada hitungan pendekatan (empiris) mengguanakan data hujan (Tunas, 2007). Adapun langkah perhitungan debit andalan dengan Metode F. J. Mock adalah pertama dengan menghitung evapotranspirasi potensial dengan Metode Penman Modifikasi, hitung limitted evapotranspirasi, lalu hitung water balance dan terakhir hitung aliran dasar dan limpasan langsung (Sutapa, 2009). Penjabaran kriteria perhitungan dan asumsi yang digunakan dalam analisis ini adalah sebagai berikut :

\section{a. Evapotranspirasi aktual $\left(\mathrm{E}_{\mathrm{a}}\right)$}

Evapotranspirasi aktual dihitung dari Evaporasi potensial metode Penman (ETo). Perhitungan evapotranspirasi $\left(E T_{0}\right)$ dengan metode Penman modifikasi (FAO) pada luasan lahan tertentu. Input data yang diperlukan berupa: temperatur, kecepatan angin, kelembaban udara dan lama penyinaran matahari (Doorenbos et al,1977; Satriyo, 2018). Persamaan yang digunakan untuk perhitungan ETo dengan metode Penmann adalah sebagai berikut:

$$
E t_{0}=c[\mathrm{~W} \cdot \mathrm{Rn}+(1-\mathrm{W}) \cdot \mathrm{f}(\mathrm{u}) \cdot(\mathrm{ea}-\mathrm{ed})]
$$

Dimana :

Eto = evapotranspirasi $(\mathrm{mm} /$ hari $)$

c $=$ faktor penyesuaian kondisi cuaca akibat siang dan malam

$\mathrm{W}=$ faktor pembobotan yang mempengaruhi dari temperatur dan ketinggian tempat

$\mathrm{Rn} \quad=$ radiasi penyinaran matahari $(\mathrm{mm} /$ hari $)$

$(1-\mathrm{W})=$ faktor bobot yang dipengaruhi oleh angin dan kelembaban

$\mathrm{f}(\mathrm{u}) \quad$ = fungsi kecepatan angin

ea = tekanan uap jenuh tergantung dari temperatur ( mbar)

ed = tekanan uap actual

$($ ea- ed $)=$ selisih tekanan uap jenuh dan aktual pada temperatur rata-rata udara

Hubungan antara Evaporasi potensial dengan Evapotranspirasi aktual dihitung dengan menggunakan persamaan (Abdulsalam, et al., 2014) :

$$
\Delta \mathrm{E}=\mathrm{Eto} \cdot\left(\frac{\mathrm{m}}{20}\right) \cdot(18-n)
$$




$$
\text { Ket: } \Delta \mathrm{E}=\mathrm{Ea}
$$

Dimana:

Ea = Evapotranspirasi aktual

ET = Evaporasi potensial metode Penman

$\mathrm{m}=$ Faktor bukaan lahan

$\mathrm{m} \quad=0$ untuk lahan dengan hutan lebat

$\mathrm{m} \quad=0$ untuk lahan dengan hutan sekunder pada

akhir musim hujan dan bertambah $10 \%$ setiap bulan kering berikutnya

$\mathrm{m}=10-40 \%$ untuk lahan yang tererosi

$\mathrm{m} \quad=30-50 \%$ untuk lahan pertanian yang diolah

(misal: sawah, ladang) $n=$ jumlah hari hujan

$n \quad=$ jumlah hari hujan

\section{b. Menghitung nilai surplus air (WS)}

Dimana :

$$
W S=R-E a
$$

WS = surplus air ( $\mathrm{mm} /$ bulan)

$\mathrm{R}=$ jumlah curah hujan setengah bulanan $(\mathrm{mm})$

$\mathrm{Ea}=$ Evapotranspirasi actual

\section{c. Menghitung nilai Infiltrasi (In)}

\section{Dimana}

$$
\ln =\mathrm{WS} \times \mathrm{I}
$$

In = infiltrasi ( $\mathrm{mm} /$ bulan),

$I=$ koefisien infiltrasi

WS $=$ surplus air ( $\mathrm{mm} /$ bulan)

d. Menghitung kandungan air tanag bulan ke-n (Vn)

Penyimpanan atau kandungan air tanah (Groundwater Storage) pada permulaan simulasi harus ditentukan penyimpanan awal (initial storage) yang besarnya tergantung dari kondisi geologi setempat dan waktu. Sebagai contoh: dalam daerah pengaliran kecil yang mana kondisi geologi lapisan bawah adalah tidak tembus air dan mungkin tidak ada air di sungai pada musim kemarau, maka penyimpanan air tanah menjadi nol (Noerhayati, 2015). Adapun persamaan sebagai berikut :

Dimana :

$$
V n=\ln \times 0,5 \times(1+K)+K \times V n-1
$$

$\mathrm{Vn}=$ kandungan air tanah bulanan ke-n $(\mathrm{mm} /$ bulan)

$\mathrm{K}=$ koefisien resesi aliran tanah (\%)

e. Menghitung nilai perubahan kandungan air tanag bulan ke-n

Perubahan groundwater storage atau kandungan air tanah adalah selisih antara groundwater storage bulan yang ditinjau dengan groundwater storage bulan sebelumnya.

Dimana:

$$
D V_{n}=V_{n}-V_{n-1}
$$

$\mathrm{dVn}=$ perubahan kandungan air tanag bulan ke- $\mathrm{n}$ ( $\mathrm{mm} /$ bulan)
$\mathrm{Vn}=$ kandungan air tanah bulanan ke-n $(\mathrm{mm} /$ bulan)

\section{f. Menghitung nilai aliran dasar (BF)}

$$
\begin{aligned}
& \mathrm{BF}=\mathrm{ln}-\mathrm{dVn} \\
& \mathrm{BF}=\text { base flow }(\mathrm{mm} / \text { bulan }) \\
& \mathrm{In}=\text { Infiltrasi }(\mathrm{mm} / \text { bulan) } \\
& \mathrm{dVn}=\text { perubahan kandungan air tanag bulan ke- } \mathrm{n} \\
& (\mathrm{mm} / \text { bulan) }
\end{aligned}
$$

\section{g. Menghitung nilai limpasan langsing (DRO)}

Dimana:

$$
\mathrm{DRO}=\mathrm{Ws}-\ln
$$

DRO = limpasan langsung $(\mathrm{mm} /$ bulan $)$

WS $=$ surplus air ( $\mathrm{mm} / \mathrm{bulan})$

In = infiltrasi ( $\mathrm{mm} /$ bulan),

\section{h. Menghitung nilau limpasan (RO)}

Dimana :

$$
\mathrm{RO}=\mathrm{BF}+\mathrm{DRO}
$$

$\mathrm{BF}=$ base flow $(\mathrm{mm} /$ bulan$)$

$\mathrm{DRO}=$ limpasan langsung $(\mathrm{mm} /$ bulan $)$

\section{i. Menghitung nilai debit aliran rata-rata (Q)}

$$
\begin{aligned}
& \text { DImana: } \\
& Q=\text { debit aliran rata-rata }\left(\mathrm{m}^{3} / \text { detik }\right) \\
& A=\text { luas daerah aliran sungai }\left(\mathrm{km}^{2}\right) .
\end{aligned}
$$

$$
Q=R O \times A
$$

\section{Analisis Debit Andalan}

Debit adalah merupakan debit minimum sungai kemungkinan debit dapat dipenuhi ditetapkan $80 \%$, sehingga kemingkinan debit sungai lebih rendah dari debit andalan sebesar 20\%. Debit andalan adalah besarnya debit yang tersedia untuk memenuhi kebutuhan air dengan resiko kegagalan yang telah diperhitungkan (Soemarto 1999). Debit andalan dihitung berdasarkan debit $(\mathrm{Q})$ rerata bulanan yang telah diurutkan dari kecil ke besar. Setelah di dapat data ketersediaan air bulanan pada tahun tertentu dilanjutkan dengan menentukan debit andalan menggunakan metode bulan dasar perencanaan dan probabilitas dari masing-masing data dihitung dengan persamaan Weibull (Limantara 2010).

$$
Q_{80}=\frac{m}{n+1} x 100 \%
$$

Dimana $Q$ adalah debit yang terjadi dengan tingkat kepercayaan $80 \%$ (probabilitas), $m$ adalah nomor urut data debit dan $\mathrm{n}$ adalah jumlah total data debit.

Dengan demikian pengertian debit andalan $80 \%$ adalah berdasarkan pada nilai debit yang mendekati atau sama dengan nilai probabilitas $(\mathrm{P})$ 80\% (Zulfikar, et al., 2012) 


\section{Analisis Kebutuhan Air}

\section{Kebutuhan Air Domestik}

Kebutuhan air untuk domestik (rumah tangga) dihitung dari jumlah penduduk di daerah perkotaan dan pedesaan yang terdapat dalam Kabupaten Manokwari. Standar kebutuhan air domestik dihitung berdasarkan dari Departemen Pemukiman dan Prasarana Wilayah (2003) dan SNI 19-6728.1 tahun 2002 (Tabel 1). Persamaan yang digunakan untuk menghitung kebutuhan air domestik sebagai berikut :

$$
Q_{D M}=365 \text { harix }\left\{\frac{q(u)}{1000} \times P(u)+\frac{q(r)}{1000} \times P(r)\right\}
$$

dimana :

$\mathrm{Q}_{\mathrm{DM}} \quad=$ kebutuhan air domestik ( $\mathrm{m}^{3} /$ tahun)

$\mathrm{q}(\mathrm{u}) \quad=$ konsumsi air daerah perkotaan (liter/kapita/hari)

$q(r) \quad=$ konsumsi air daerah pedesaan (liter/kapita/hari)

$P(u) \quad=$ jumlah penduduk kota (jiwa)

$P(r) \quad=$ jumlah penduduk desa (jiwa)

Tabel 1. Standar kebutuhan air domestik

\begin{tabular}{|c|c|c|}
\hline Jenis kota & Jumlah penduduk & $\begin{array}{c}\text { Jumlah kebutuhan } \\
\text { air } \\
\text { (liter/orang/hari) }\end{array}$ \\
\hline Metropolitan & $>2.000 .000$ & $>210$ \\
\hline Metropolitan & $\begin{array}{r}1.000 .000- \\
2.000 .000\end{array}$ & $150-210$ \\
\hline Besar & $\begin{array}{l}500.000- \\
1.000 .000\end{array}$ & $120-150$ \\
\hline Besar & $100.000-500.000$ & $100-150$ \\
\hline Sedang & $20.000-100.000$ & $90-100$ \\
\hline Kecil & $3.000-20.000$ & $60-100$ \\
\hline
\end{tabular}

Sumber : Praswil 2003 dan SNI 19-6728.1-2002.

Kebutuhan air domestik akan dipengaruhi oleh pola konsumsinya seperti penduduk kota menggunakan air lebih banyak dibandingkan penduduk desa. Berdasarkan SNI 19-6728.1 (2002) tentang sumberdaya air penduduk kota membutuhkan 120 liter/hari/kapita, sedangkan penduduk pedesaan memerlukan 60 liter/hari/kapita.

\section{Kebutuhan air industri}

Kebutuhan air industry merupakan kebutuhan air untuk proses industry dan kebutuhan pekerja di industry tersebut. Perhitungan kebutuhan air industri dapat diperhitungkan berdasarkan atas jumlah karyawan, luas air industri dan jenis/tipe industry SNI 6728.1 (2015). Pada penelitian ini, perhitungan kebutuhan air industri dihitung berdasarkan jumlah hari kerja dan jumlah tenaga kerja dengan menggunakan tiga jenis kelas industri yaitu (Purwanto 1995) :

1) Industri besar membutuhkan air sebesar 151-350 $\mathrm{m} 3 /$ hari
2) Industri sedang membutuhkan air sebesar 51-150 $\mathrm{m} 3 /$ hari

3) Industri kecil membutuhkan air sebesar 5-50 $\mathrm{m} 3 / \mathrm{hari}$

Persamaan yang digunakan untuk menghitung kebutuhan air industri sebagai berikut :

$$
Q I D=H k(T k x Q i)
$$

dimana :

$$
\begin{array}{ll}
\text { QID } & \text { kebutuhan air industri (m3/tahun) } \\
\text { Hk } & =\text { jumlah hari kerja (tahun) } \\
\text { Tk } & =\text { jumlah tenaga kerja (jiwa) } \\
\text { Qi } & =\text { kebutuhan air skala industri (m3/hari) }
\end{array}
$$

\section{Kebutuhan Air Irigasi}

Kebutuhan air irigasi adalah jumlah air total yang akan diberikan pada petak sawah dari jaringan irigasi. Besarnya kebutuhan air di petak sawah dipengaruhi oleh banyaknya air yang dibutuhkan untuk pengolahan tanah dan pertumbuhan tanaman (Sosrodarsono dan Takeda 1976).

Kebutuhan air untuk irigasi diperhitungkan berdasarkan luas sawah irigasi teknis, semi teknis dan sederhana yang terdapat dalam Kabuapten Manokwari dan dipergunakan dalam waktu 1 (satu) tahun. Persamaan yang digunakan adalah sebagai berikut (SNI 19-6728.1 2002) :

$$
Q_{I R}=L \times I t \times a
$$

dimana :

$Q_{\mathbb{I R}}=$ kebutuhan air untuk irigasi sawah ( $\mathrm{m}^{3} /$ tahun)

$\mathrm{L} \quad=$ luas sawah (ha)

It = intensitas penanaman dalam semusim/tahun $3600 \mathrm{det} / \mathrm{jam} \times 24 \mathrm{jam} / \mathrm{hari} \times 120 \mathrm{hari} / \mathrm{musim}$

$\mathrm{a}=$ standar penggunaan air irigasi (It/ha/tahun) Standar penggunaan air merujuk pada Dinas PU Pengairan Provinsi Aceh yaitu $1 \mathrm{It} / \mathrm{det} / \mathrm{ha}$.

\section{Kebutuhan Air Peternakan}

Peternakan juga membutuhkan air untuk minum ternak. Jenis ternak yang diperhitungkan dalam penelitian ini adalah sapi/kerbau/kuda, kambing/domba, dan unggas. Jenis ternak yang berbeda membutuhkan jumlah air yang berbeda pula. Standar yang digunakan untuk menghitung kebutuhan air peternakan adalah SNI 19-6728.1 (2002) yang didasarkan dari hasil penelitian tentang sumberdaya air nasional tahun 1992, disajikan pada Tabel 5 dan dengan persamaan sebagai berikut :

$$
\begin{gathered}
Q_{L}=365 \text { harix }\left\{Q_{(c / b)} x P_{(c / b)}+Q_{(s / g)} x P_{(s / g)}\right. \\
\left.+Q_{(p o)} x P_{(p o)}\right\}
\end{gathered}
$$

dimana :

$$
\begin{array}{ll}
Q_{\mathrm{L}} & =\text { kebutuhan air untuk ternak ( } \mathrm{m}^{3} / \text { tahun) } \\
\mathrm{Q}_{(\mathrm{c} / \mathrm{b})} & =\text { kebutuhan air untuk sapi/kerbau/kuda } \\
& \text { (liter/ekor/hari) } \\
\mathrm{Q}_{(\mathrm{s} / \mathrm{g})}= & \text { kebutuhan air untuk domba/kambing }
\end{array}
$$


(liter/ekor/hari)

$Q_{(p o)} \quad=$ kebutuhan air untuk unggas (liter/ekor/hari)

$P_{(c / b)} \quad=$ jumlah sapi/kerbau/kuda (ekor)

$\mathrm{P}_{(\mathrm{s} / \mathrm{g})} \quad=$ jumlah domba/kambing (ekor)

$P_{(p o)} \quad=$ jumlah unggas (ekor)

Tabel 2. Standar kebutuhan air peternakan

\begin{tabular}{lc}
\hline \multicolumn{1}{c}{ Jenis ternak } & $\begin{array}{c}\text { Kebutuhan air } \\
\text { (liter/ekor/hari) }\end{array}$ \\
\hline Sapi / kerbau / kuda & 40 \\
Kambing / domba & 5 \\
Unggas & 0,6 \\
\hline \multicolumn{2}{c}{ Sumber : SNI 19-6728.1-2002. }
\end{tabular}

\section{Kebutuhan Air Total Kabuapten Manokwari}

Kebutuhan air total di DAS Krueng Aceh dapat diperoleh dengan menjumlahkan kebutuhan air dari 5 (lima) sektor peruntukan tersebut dengan persamaan sebagai berikut :

$$
Q_{\text {Total }}=Q_{D M}+Q_{I D}+Q_{I R}+Q_{L}
$$

dimana :

$\mathrm{Q}_{\text {Total }}=$ kebutuhan air total $\left(\mathrm{m}^{3} /\right.$ tahun $)$

$Q_{D M}=$ kebutuhan air domestik ( $\mathrm{m}^{3} /$ tahun)

$Q_{I D} \quad=$ kebutuhan air industri ( $\mathrm{m}^{3} /$ tahun $)$

$Q_{\mathbb{R}} \quad=$ kebutuhan air irigasi ( $\mathrm{m}^{3} /$ tahun)

$Q_{L} \quad=$ kebutuhan air peternakan ( $\mathrm{m}^{3} /$ tahun)

\section{Neraca Air Kabuapten Manokwari}

Neraca air Kabuapten Manokwari merupakan keseimbangan antara jumlah air yang masuk (inflow) dan keluar (outflow) di suatu wilayah untuk suatu periode tertentu dari proses sirkulasi air. Apabila neraca air positif maka tidak terjadi kekurangan air (surplus), dan apabila neraca air negatif maka mengindikasikan adanya kekurangan air (defisit) pada DAS tersebut. Untuk mengetahui neraca air DAS Krueng Aceh dilakukan perhitungan menggunakan persamaan :

$$
Q_{\text {Ketersediaan }}-Q_{\text {Kebutuhan }}=\Delta S
$$

dimana :

$$
\begin{array}{ll}
\text { Qketersediaan } & =\text { Total ketersediaan debit }\left(\mathrm{m}^{3} / \mathrm{bulan}\right) \\
\text { Qkebutuhan } & =\text { Total kebutuhan debit }\left(\mathrm{m}^{3} /\right. \text { bulan) } \\
\Delta S & =\text { Perubahan kuantitas air }\left(\mathrm{m}^{3} / \mathrm{bulan}\right)
\end{array}
$$

\section{HASIL DAN PEMBAHASAN}

\section{Evapotranspirasi}

Analisis evapotranspirasi potensial pada Kabupaten Manokwari dilakukan menggunakan metode penman modifikasi yang didukung oleh data ilkim yang di proleh dari BPS Kabupaten Manokwari selama 10 tahun (2010-2018). Perhitungan evapotranspirasi dimulai dengan perhitungan curah hujan yang mencakup daerah lokasi penelitian, selain itu diperlukan data temperatur, kelembapan udara, kecepatan angin dan penyinaran matahari. Berdasarkan data-data yang diperoleh maka perhitungan evapotranspirasi metode Penman dapat di sajikan dalam gambar 1 .

Berdasarkan hasil analisis rata-rata besarnya evapotranspirasi potensial (ET0) berkisar antara 312.7-509.8 mm/bulan. Nilai evapotranspirasi tertinggi pada bulan Oktober sebesar $509.8 \mathrm{~mm} / \mathrm{bulan}$ dan terendah terjadi pada bulan Juni sebesar 312.7 $\mathrm{mm} /$ bulan. Berdasarkan Metode Penman besarnya evapotranspirasi potensial (ET0) dipengaruhi oleh koefisien refleksi, dimana refleksi ini tergantung pada vegetasi dengan penggunaaan lahan.

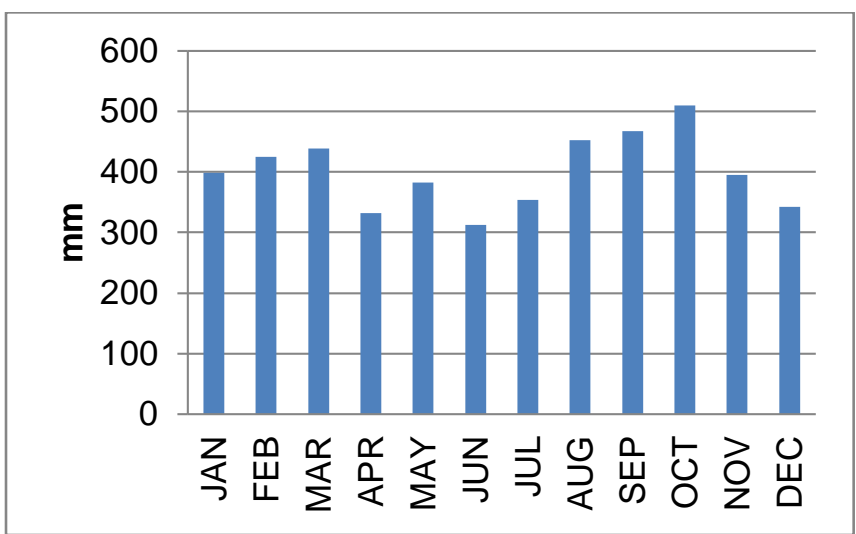

Gambar 1. Rata-rata evapotranspirasi (ET0) bulanan Kabupaten Manokwari

\section{Debit Andalan}

Debit andalan di Kabupaten Manokwari dihasilkan dari metode Mock dengan parameter-parameter yang disarankan oleh Mock. Perhitungan debit andalan dengan menggunakan metode F. J. Mock mengacu pada data curah hujan dan data evapotranspirasi. Data evapotranspirasi ini kemudian dijadikan input untuk perhitungan debit andalan. Selain data evapotranspirasi, diperlukan juga data curah hujan bulanan, lama hari hujan per bulan, asumsi infiltrasi, koefisien simpanan tanah dan luas permukaan terbuka. Asumsi infiltrasi yang digunakan dalam perhitungan ini yaitu sebesar $40 \%$. Adapun hasil dari analisis dengan menggunakan metode Mock dapat dilihat pada gambar 2 .

Gambar 2 menunjukan rekapitulasi perhitungan ratarata debit bulanan Kabupaten Manokwari. Debit ratarata bulanan Maksimum terjadi pada bulan April sebesar $24.08 \mathrm{~m} 3 /$ detik, sedangkan debit rata-rata minimum terjadi pada bulan Oktober sebesar 7.07 $\mathrm{m}^{3} /$ detik. 


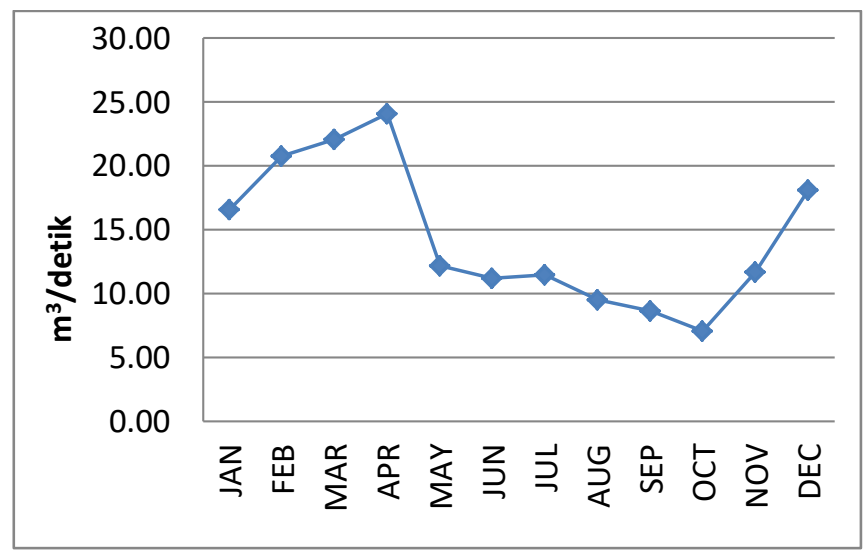

Gambar 2. Grafik rata-rata debit andalan Kabupaten Manokwari periode tahun 2010-2018

Pendugaan debit air tahunan menggunakan mock dengan menunjukan kebutuhan air berdasarkan debit andalan yang dikonversikan ke satuan volume per detik dapat dilihat pada gambar 3. Berdasarkan konsep water balance menghsilkan debit andalan maksimum terjadi pada debit tahunan pada tahun 2013 sebesar 211.157 (m3/dt). Sedangkan debit andalan minimum terjadi pada tahun 2010 dengan volume sebesar 96.585 (m3/dt).

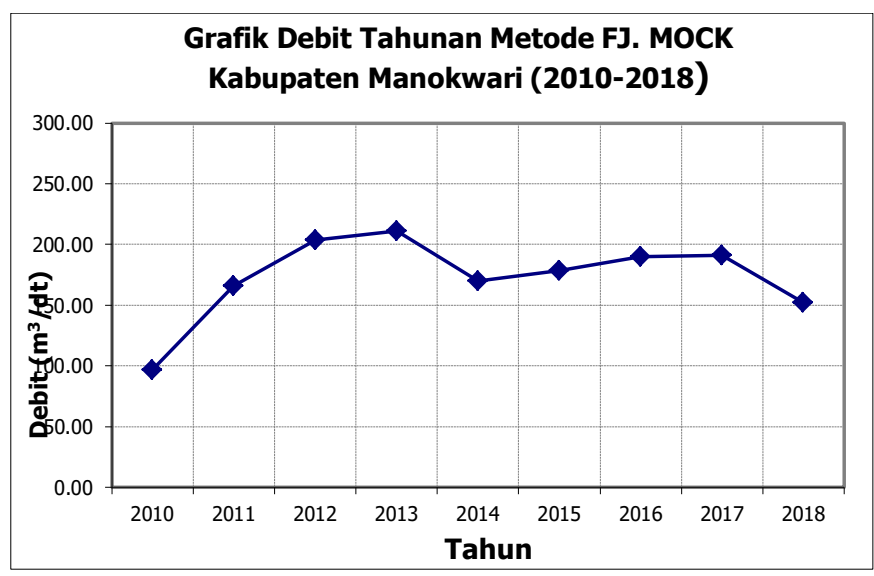

Gambar 3. Grafik Debit Tahunan Metode FJ. Mock Kabupaten Manokwari

\section{Pasokan air (Water supply)}

Analisis pasokan air (Water supply) mengunakan air permukaan yang berasal dari rata-rata debit tahunan dengan menggunakan metode FJ. Mock. Jumlah air permukaan yang tersedia di Kabupaten Manokwari pada tahun 2018 sebesar 398570549 m3/tahun. Jumlah pasokan air tertinggi bulan Maret sebesar 68 $769488 \mathrm{m3}$, karena pada bulan ini terjadi curah hujan yang cukup tinggi yang berpengaruh pada debit sungai. Jumlah pasokan air di Kabupaten Manokwari tahun 2018 disajikan pada Tabel 3.
Tabel 3. Pasokan air Kabupaten Manokwari 2018

\begin{tabular}{lrc}
\hline Bulanan & $\begin{array}{r}\text { Debit rata-rata } \\
\left(\mathrm{m}^{3} / \mathrm{dt}\right)\end{array}$ & $\begin{array}{c}\text { Volume Air } \\
\left(\mathrm{m}^{3} / \text { bulan }\right)\end{array}$ \\
\hline Januari & 8.84 & 23683114 \\
Februari & 22.11 & 53495310 \\
Maret & 25.68 & 68769488 \\
Aprio & 14.45 & 37442166 \\
Mei & 5.84 & 15648127 \\
Juni & 8.34 & 21621975 \\
Juli & 12.60 & 33754151 \\
Augustus & 4.69 & 12574937 \\
September & 4.54 & 11776916 \\
Oktober & 7.66 & 20518431 \\
November & 17.82 & 46178360 \\
Desember & 19.83 & 53107572 \\
\hline Jumlah & 152.41 & 398570549 \\
\hline
\end{tabular}

Keterangan : Volume air = debit rata-rata $\mathrm{x}$ jumlah hari x 86400

\section{Kebutuhan air rumah tangga (Domestik)}

Kebutuhan air masyarakat Kabupaten Manokwari di pasok dari sungai dan anak-anak sungai serta sumbersumber mata air yang berada di dalam hutan yang disalurkan melalui pipa-pipa sehingga sampai ke pemukiman. Selain itu juga yang mengambil dari air sumur dan air PDAM. Jumlah penduduk yang ada di Kabupaten Manokwari pada tahun 2018 sebanyak 1 73020 jiwa dengan kebutuhan air sebanyak 6315230 (m3/tahun/kapita). Kebutuhan air rumah tangga di kecamatan Manokwari Barat merupakan kebutuhan terbesar yaitu sebesar 3537726 (m3/tahun/kapita) dengan jumalh penduduk sebesar 96924 jiwa.

Tabel 4. Kebutuhan air rumah tangga

\begin{tabular}{lrr}
\hline \multicolumn{1}{c}{ Kecamatan } & $\begin{array}{c}\text { Jumlah } \\
\text { penduduk }\end{array}$ & $\begin{array}{c}\text { konsumsi air } \\
\left(\mathrm{m}^{3} / \text { tahun/kapita }\right)\end{array}$ \\
\hline Warmare & 8821 & 321967 \\
Prafi & 16453 & 600535 \\
Manokwari Barat & 96924 & 3537726 \\
Manokwari Timur & 10401 & 379637 \\
Manokwari Utara & 2557 & 93331 \\
Manokwari Selatan & 15281 & 557757 \\
Tanah Rubu & 2193 & 80045 \\
Masni & 15642 & 570933 \\
Sidey & 4748 & 173302 \\
\hline Jumlah & 173020 & 6315230 \\
\hline
\end{tabular}




\section{Kebutuhan air Industri}

Berdasarkan hasil dari perhitungan kebutuhan air industry di Kabupaten Manokwari sebesar 11273520 m3. Dengan kebutuhan air industri terbesar terdapat pada kecamatan Manokwari Utara sebesar 1998720 $\mathrm{m} 3$, hal ini dikarenakan Manokwari utara memiliki tenaga kerja industri yang cukup banyak yaitu sebanyak 1058 tenaga kerja.

Tabel 5. Kebutuhan air industry

\begin{tabular}{lc}
\hline \multicolumn{1}{c}{ Kecamatan } & $\begin{array}{c}\text { Total Kebutuhan Air Industri } \\
\left(\mathrm{m}^{3} / \text { thn }\right)\end{array}$ \\
\hline Warmare & 1241760 \\
Prafi & 1241760 \\
Manokwari Barat & 1139760 \\
Manokwari Timur & 1579920 \\
Manokwari Utara & 1998720 \\
Manokwari Selatan & 1057200 \\
Tanah Rubu & 1327200 \\
Masni & 1269600 \\
Sidey & 417600 \\
\hline \multicolumn{1}{c}{ Jumlah } & 11273520 \\
\hline
\end{tabular}

\section{Kebutuhan air pertanian (air sawah)}

Luas sawah di Kabuapten Manokwari seluas 2324 ha, sawah yang paling luas tersebar di Kecamatan Prafi seluas 1035 ha. Air yang digunakan untuk mengairi sawah berasal dari sungai dan air hujan. Musim tanam padi di Kabupaten Manokwari setiap tahun sebanyak 2 kali. Kebutuhan air yang dipergunakan untuk tanaman padi sawah di Kabupaten Manokwari sebanyak 48190 464 m3 selama satu tahun. Rincian jumlah kebutuhan air sawah pertahun setiap kecamatan dapat dilihat pada Tabel 6.
Tabel 6. Kebutuhan air pertanian

\begin{tabular}{lrr}
\hline Kecamatan & $\begin{array}{c}\text { Luas } \\
\text { Sawah } \\
(\mathrm{Ha})\end{array}$ & $\begin{array}{c}\text { Kebutuhan air per } \\
\text { tahun } \\
\left(\mathrm{m}^{3} / \text { thn }\right)\end{array}$ \\
\hline Warmare & 15 & 311040 \\
Prafi & 1035 & 21461760 \\
Manokwari Barat & - & \\
Manokwari Timur & - & \\
Manokwari Utara & - & \\
Manokwari Selatan & - & \\
Tanah Rubu & - & 13208832 \\
Masni & 637 & 13208832 \\
Sidey & 637 & 48190464 \\
\hline Jumlah & 2324 & \\
\hline
\end{tabular}

\section{Kebutuhan air peternakan}

Peternakan menjadi salah satu tumpuan yang dapat menopang perekonomian masyarakat pedesaan di Kabupaten Manokwari. Pemeliharaan ternak yang dilakukan hanya bersifat sampingan bukan menjadi penghasilan pokok, sehingga hampir setiap kepala keluarga mempunyai peliharaan ternak. Jenis ternak yang banyak dipelihara oleh masyarakat adalah sapi, kerbau, kambing, domba, babi, ayam dan itik. Air merupakan kebutuhan vital bagi makhluk hidup termasuk ternak, kebutuhan air untuk ternak dihitung berdasarkan asumsi yang digunakan oleh Nippon Koei Co Ltd (1993). Kebutuhan air untuk sapi dan kerbau ditentukan sebesar 40 liter/ekor/hari, domba/kambing 5 liter/ekor/hari, babi 6 liter/ekor/hari, unggas sebesar 0.6 liter/ekor/hari (Triatmodjo 2009). Berdasarkan data BPS tahun 2018 jumlah ternak yang dipelihara di 9 kecamatan di Kabuapten Manokwari dapat dilihat pada Tabel 7.

Tabel 7. Kebutuhan air peternakan

\begin{tabular}{ccccccc}
\hline \multirow{2}{*}{ Kecamatan } & \multicolumn{9}{c}{ Kebutuhan air ( $\mathrm{m}^{3} /$ tahun } & & Total Kebutuhan Air \\
& Sapi & Kambing & Babi & Ayam & Itik & Peternakan m3/th \\
\hline Warmare & 57991 & 1661 & 6926 & 12503 & 3121 & 82201 \\
Prafi & 32529 & 4530 & 8747 & 20059 & 4536 & 70401 \\
Manokwari Barat & 34398 & 847 & 9329 & 122234 & 0 & 166808 \\
Manokwari Timur & 3913 & 611 & 6459 & 146659 & 0 & 157642 \\
Manokwari Utara & 19126 & 4583 & 8824 & 13895 & 0 & 46428 \\
Manokwari & & & & & & \\
Selatan & 39172 & 294 & 8300 & 19671 & 80 & 67517 \\
Tanah Rubu & 12337 & 434 & 7430 & 12751 & 1751 & 34702 \\
Masni & 90681 & 4849 & 7368 & 15281 & 4329 & 122507 \\
Sidey & 77219 & 1538 & 5948 & 14105 & 3408 & 102219 \\
\hline Jumlah & 367365 & 19347 & 69330 & 377158 & 17225 & 850425 \\
\hline
\end{tabular}




\section{Kebutuhan air total}

Kebutuhan air total adalah jumlah air yang diperlukan untuk memenuhi kebutuhan air rumah tangga (domestik) dan industri, kebutuhan air pertanian (sawah) dan kebutuhan air untuk ternak. Total kebutuhan air di Kabuapten Manokwari sebanyak 66 $629639 \mathrm{~m}^{3} /$ tahun. Kebutuhan air terbesar digunakan untuk keperluan pertanian 17\% yaitu sebesar 48190 $464 \mathrm{~m}^{3} /$ tahun, sedangkan kebutuhan air terendah untuk sektor peternakan adalah $1 \%$ atau sebesar 850 $425 \mathrm{~m}^{3} /$ tahun. Perhitungan kebutuhan air (Water demand) total di Kabupaten Manokwarii tahun 2018 dapat dilihat pada Tabel 8.

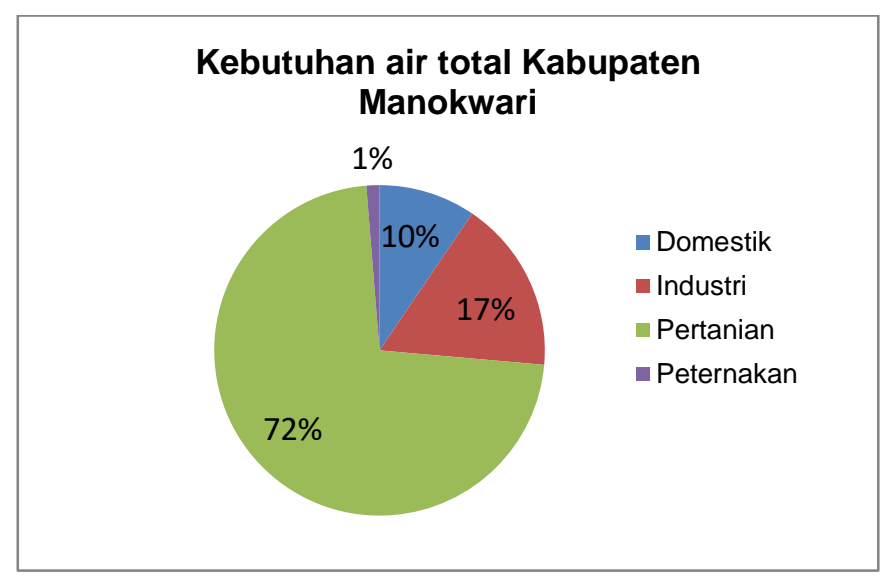

Gambar 4. Kebutuhan air total Kabupaten Manokwari

\section{Neraca Pasokan dan Kebutuhan Air}

Perhitungan neraca air dilakukan dengan pendekatan supply dan demand dengan membandingkan kebutuhan dan pasokan. Kebutuhan air (Demand) dalam penelitian ini dihitung dari kebutuhan air sektor rumah tangga (domestik)dan industri, kebutuhan air sektor peternakan, dan kebutuhan air sektor pertanian sawah. Sedangkan pasokan air (water supply) dihitung dari perhitungan bulanan dengan menggunakan metode mock.

Pasokan air Kabupaten Manokwari tahun 2018 sebanyak 395,035,003 m3/tahun. Sedangkan kebutuhan air Kabuapten Manokwari tahun 2018 dari 4 sektor sebanyak 66629 639m3/tahun. Berdasarkan perhitungan neraca air kebutuhan air sepanjang tahun masih dapat dipenuhi dari pasokan air yang ada sebesar $331940910 \mathrm{m3} /$ tahun.

Tabel 9. Neraca air Kabupaten

\begin{tabular}{lcrr}
\hline \multicolumn{1}{c}{ Bulanan } & $\begin{array}{c}\text { Pasokan air } \\
\left(\mathrm{m}^{3}\right)\end{array}$ & $\begin{array}{c}\text { Kebutuhan air } \\
\left(\mathrm{m}^{3}\right)\end{array}$ & $\begin{array}{c}\text { Neraca air } \\
\left(\mathrm{m}^{3}\right)\end{array}$ \\
\hline Januari & 23683114 & 7790669 & 15892446 \\
Februari & 53495310 & 7036733 & 46458577 \\
Maret & 68769488 & 7790669 & 60978819 \\
April & 37442166 & 7539357 & 29902810 \\
Mei & 15648127 & 1566067 & 14082060 \\
Juni & 21621975 & 1515549 & 20106426 \\
Juli & 33754151 & 1566067 & 32188085 \\
Agustus & 12574937 & 1566067 & 11008870 \\
September & 11776916 & 7539357 & 4237560 \\
Oktober & 20518431 & 7790669 & 12727763 \\
November & 46178360 & 7539357 & 38639003 \\
Desember & 53107572 & 7389081 & 45718491 \\
\hline Jumlah & 398570549 & 66629639 & 331940910 \\
\hline
\end{tabular}

\section{KESIMPULAN}

1. Berdasarkan hasil perhitungan debit bulanan tahun 2010 sampai dengan tahun 2018 dan rekapitulasi debit rata-rata bulanan dengan menggunakan analisis metode Mock besarnya debit andalan minimum sebesar 7.07 (m3/dt) sedangkan debit maximum sebesar 24.08 (m3/dt). Sedangkan besarnya debit andalan minimum tahunan sebesar $96.59(\mathrm{~m} 3 / \mathrm{dt})$ pada tahun 2010 dan debit andalan maximum tahunan sebesar 211.18 (m3/dt) pada tahun 2010. Dari hasil perhitungan Debit andalan Probabilitas $80 \%$ nilai probabilitas debit tahunan 2010 sampai dengan 2018 terdapat pada tahun 2018 yaitu sebesar 152,41 (m3/dt) . 
2. Potensi ketersediaan air pada kabupaten Manokwari hingga tahun 2018 adalah sebesar 398 $570549 \mathrm{~m} 3$ dan total kebutuhan air konsumsi untuk penggunaan sebanyak 66629639 m3, sehingga surplus air baku.

3. Konsumsi kebutuhan air terbesar di dominasi oleh sektor pertanian yaitu mencapai $48 \quad 190464$ $\mathrm{m} 3 /$ tahun, dan permintaan konsumsi air terendah yaitu pada sektor peternakan sebanyak 850425 m3/tahun.

\section{REFERENSI}

Abdulsalam, R., Binilang, A., \& Halim, F. (2014). Analisis Potensial Sungai Atep Oki Serta Sesain Dasat Bangunan Slpil untuk Pembangkit Listrik Tenaga Air. Jurnal Sipil Statik , 225-232.

(BPS) Badan Pusat Statistik. (2018). Kabuapten Manokwari Dalam Angka Tahun 2018. Manokwari (ID) : BPS Kabupaten Manokwari.

Doorenbos J, Pruitt WO. (1977). Guidelines for Prediction Crop Water Requirment, Irigation and Drainage. Roma (R): FAO.

Gustiana M, Azmeri, Yulianur A. (2014). Optimasi Parameter Model Dr.Mock Untuk Pengelolaan Daerah Aliran Sungai. Jurnal Teknik Sipil Pascasarjana Universitas Syiah Kuala. 3(1): 36-45

Limantara LM. (2010). Hidrologi Praktis. Bandung (ID): Lubuk Agung.

Noerhayati E.(2015). Model Neraca Air Daerah Aliran Sungai dengan MINITAB. Malang (ID): Badan Penerbit Fakultas Ekonomi Universitas Islam Malang

Purwato S. (2017). Model Analisis Daya Dukung DAS Berdasarkan Jejak Air Untuk Pengelolaan DAS Krueng Aceh. Bogor (ID): Institut Pertanian Bogor.

Satriyo P. (2018). Analisis Daya Dukung DAS Berdasarkan Jejak Air Untuk Pengelolaan DAS Krueng Aceh. Bogor (ID): Institut Pertanian Bogor.

[SNI] Standar Nasional Indonesia. (2002). Penyusunan neraca sumber daya Bagian 1: Sumber daya air spasial. Badan Standardisasi Nasional. Jakarta (ID): SNI 19-6728.1-2002.

[SNI] Standar Nasional Indonesia. (2015). Penyusunan neraca sumber daya Bagian 1: Sumber daya air spasial. Badan Standardisasi Nasional. Jakarta (ID): SNI 6728.1-2015.

Sutapa, I. W. (2009). Studi Potensi Pengembangan Sumber Daya Air di Kota Ampana Sulawesi Tengah. 7, $13-23$.
Tunas, I. G. (2007). Optimasi Parameter Model untuk Menghitung Debit Andalan Sungai MIU. SMARTek, 5, 40-48.

Zulfikar, l., Jasin, M. I., Binilang, A., \& Mamoto, J. D. (2012). Analisis Debit Sungai Munte Dengan Metode Mock dan Metode Nreca untuk Kebutuhan Pembangkit Listrik Tenaga Air . 34-38. 